\title{
Harold Nicolson and Appeasement
}

John W. Young

Harold Nicolson is remembered for many aspects of a remarkably varied life. The son of a Permanent Under-Secretary of the Foreign Office, he became a successful diplomat himself, with a role in shaping the 1919 Paris peace settlement. He served as far afield as Constantinople, Tehran and, in the late 1920s, Berlin. He was a prodigious writer, his publication list including novels, a memoir of the Paris peace conference, the official biography of George $\mathrm{V}$ and two studies of diplomacy. Nicolson's life is peculiarly well documented thanks to his diaries, most of which have been published, and he has been the centre of attention too because of his unusual relationship with his wife, Vita Sackville-West - both were bisexual - with whom he created the gardens at Sissinghurst Castle, Kent. At different times he was a journalist, broadcaster, member of parliament and government minister, yet somehow his career never reached the heights he hoped. Under pressure from his wife, he gave up his diplomatic career in 1929, in favour of writing a column for the Evening Standard, but rapidly became disaffected with the triviality of the job and for a time was involved with Oswald Mosley, who later led the British Union of Fascists. Nicolson was a candidate for Mosley's New Party in the 1931 general election, but broke with him the following year when his fascist leanings became clear. Elected an MP in 1935 for West Leicester, Nicolson sat in the Commons for ten years but, as a member of the small National Labour group in the governing coalition, had limited 
long-term prospects. In his whole time as an MP he made barely two dozen speeches, while his ministerial career, as Parliamentary Secretary to the Ministry of Information, lasted little more than a year (1940-41). ${ }^{1}$

Yet Nicolson's time in parliament was significant. His diplomatic experience meant that he carried some weight in debates on foreign policy, he was an ally and admirer of Anthony Eden, and in 1938 spoke out strongly against Neville Chamberlain's policy of Appeasement. He has a reputation as an 'early and consistent warner of the dangers of appeasing the dictators... ${ }^{2}$ This essay focuses on that period of his life to ask how he might fit into historiographical debates on the subject, especially in light of the questions David Dilks and others have raised about Chamberlain's critics. With the outbreak of the Second World War, accounts of the late 1930 s became dominated by the 'guilty men' school, with its condemnation of the Prime Minister for his supposedly weak-kneed approach to the dictators. However, with the opening of official files around 1970, Dilks and other revisionists showed that Chamberlain's choices were limited. With an economy recovering only fitfully from the 'slump', a population who ideally wished to remain at peace, a paucity of allies and a potential risk of having to fight three aggressive powers - Germany, Italy and Japan - simultaneously, Britain was in an unenviable strategic predicament. In such circumstances it made sense to try to buy Adolf Hitler with concessions, especially since many people believed Germany had been treated harshly in the Treaty of Versailles and when there was no coherent, realistic alternative to Appeasment. ${ }^{3}$ The issue of alternatives has recently been the focus of renewed interest, not least in the work of Andrew Stedman. ${ }^{4}$ This chapter focuses on just one 
of Chamberlain's better-known critics - Nicolson - to ask how consistent and wellconsidered were his criticisms.

\section{Abyssinia, the Rhineland and Spain}

Nicolson's dislike of fascism was clear from an early date, even as he dabbled on its fringes. During his involvement with Oswald Mosley, Nicolson urged his friend 'not to get muddled up with the fascist crowd. ${ }^{5}$ And when Christopher Hobhouse, a New Party supporter, returned from a visit to Germany in early 1932, Nicolson's showed an instinctive dislike of fascist methods: 'Christopher... says that the Fuhrer contends that we British Hitlerites are trying to do things like gentlemen. That will never do. We must be harsh, violent and provocative. I do not care for this aspect of my future functions. ${ }^{6}$ Visiting Italy with Mosley, Nicolson was impressed by the efficiency of Mussolini's regime 'on paper', but feared 'it destroys individuality. It also destroys liberty. ${ }^{7}$ While in Germany soon afterwards he wrote of Nazism as a 'doctrine of despair. ${ }^{8}$ He later explained to his wife that 'my loathing for Fascism is due to the fact that I hate the type of mind that believes in brute force. It is not nobility on my part but a sort of physical loathing which I suppose is based on cowardice.' ${ }^{9}$ Indeed, Nicolson's involvements of the early 1930s, gave him an insight into its methods that others lacked. So, when the threat of fascist aggression actually made itself evident a few years later, he was better prepared than most to understand its violent thirst for power and to resist this. Yet, for all that, his will to resist was diluted by an appreciation of diplomatic realities, a sense of loyalty to his political colleagues and an abhorrence of war, as well as by some personal weaknesses that sometimes led him to shun the parliamentary limelight. 
Nicolson's maiden speech in the House of Commons, on 19 December 1935, coincided with growing concern about fascist aggression and involved the HoareLaval pact. This notorious agreement provoked public outrage because it revealed the willingness of Britain and France to strike a deal that rewarded Italy's Benito Mussolini for his recent invasion of Abyssinia (Ethiopia). As Nicolson said, 'Many of us on Monday last, when we read or heard of this new Paris plan, were filled with a feeling which I can only describe as bewildered despair...'. But the novice MP, keen to make a name for himself as a parliamentarian, did not push his criticism of government policy too far. He welcomed a reassuring speech from the Prime Minister, Stanley Baldwin, and praised the former Foreign Secretary, Samuel Hoare, for 'his public-spirited act of self-sacrifice' in resigning once the national outrage became apparent. Nicolson also took a singularly unsympathetic view of the predicament of Mussolini's victim, declaring: 'I do not think the main object of the efforts of this Government or of this country should be the preservation of Abyssinian integrity.' He even said that he did not 'consider the terms of the Hoare-Laval pact unreasonable,' which hardly suggested someone opposed in principle to handing small countries to dictators.

In fact, apart from regretting the damage done to the League of Nations by such a deal been struck behind its back, Nicolson's objections to Hoare's diplomacy were largely procedural and revolved around two points. First, there was the supposed danger of dealing with Italian diplomats, remarks that are worth repeating at some length because they reveal an oddly simplistic view of the significance of supposed national traits in international affairs: 
Members would agree with me if they had had my experience - that you must never negotiate with an Italian on his own level. It is impossible to do so, because he is much more ingenious and much more subtle than we are ourselves. It is essential, when dealing with an Italian, to adopt an entirely different level, the level of your own integrity, and that level is so far removed from the Italian level that you will be perfectly certain of not getting inveigled into his coils.

Then there was another lesson learned from Nicolson's diplomatic career, the dangers inherent in personal diplomacy between politicians: 'It is a terrible mistake to conduct negotiations between Foreign Ministers...'; international negotiations were best left to the professionals. 'Diplomacy is not the art of conversation. It is the art of the exchange of documents in a carefully considered and precise form and in such a way that they cannot be repudiated later... Diplomacy by conference is a mistake. ${ }^{, 10}$ Despite the praise he received for the speech, Nicolson realised that 'the matter was too thin. ${ }^{11}$

In a way, there was a broad consensus within Britain's political leadership on the need for some measure of 'appeasement' in the mid-thirties, in the sense of making concessions to countries who had been treated unjustly in the past. Most accepted that Germany was harshly dealt with in the Treaty of Versailles and that it was worth offering something to Hitler if this would secure the peace. Nicolson met with Anthony Eden, the League of Nations minister, in February 1936 and the pair agreed that the key aim was to avoid war by striking a deal that involved making 'great concessions to German appetites provided they will sign a disarmament treaty and join the League of Nations. ${ }^{12}$ Whatever his dislike of Italian diplomatic methods, 
Nicolson soon focused his attention on the potential German menace. The Conservative MP, 'Chips', Channon recorded in his diary in late February 1936, Nicolson giving to the Foreign Affairs Committee 'a brilliant address on AngloGerman relations. It was shrewd, but alarming and we almost heard the tramp-tramp of the troops. Harold predicted that trouble would come from the German source in 1939 or $1940 \ldots{ }^{13}$ In this he may have been influenced by his old friendship with Robert Vansittart, Permanent Under-Secretary of the Foreign Office in 1930-37, with whom he continued to meet socially. ${ }^{14}$ Vansittart, too, focused on the German menace though, in trying to create a strong anti-Nazi front, he may have been more ready than Nicolson to overlook Mussolini's misbehaviour. Indeed, the Permanent UnderSecretary had been a key advocate of the Hoare-Laval pact. ${ }^{15}$

On 7 March 1936, Hitler took his first step to overthrow the post-war settlement and expand German power via a sudden fait accompli, when he remilitarised the Rhineland. In doing so, he violated both the Treaty of Versailles and the 1925 Locarno Pact. Nicolson later recalled that, 'It was not pleasant during those weeks to be a Cassandra exposing weakness, indicating danger and prophesying disaster. ${ }^{16}$ But if this is intended as a reflection on his own role at the time, it exaggerates. True, at first he was deeply troubled and ideally wanted firm action. $\mathrm{He}$ told his wife, 'we should refuse to negotiate with Germany until she evacuates the Rhineland and should force her out of it. It is really essential to demonstrate that Treaties cannot be torn up by violence.' But, as on the Abyssinian question, he soon tempered his determination with a string of second thoughts. For one thing, British public opinion was 'terrified of war... And the result is that we shall give way to Germany and let down France... ${ }^{17}$ In the Commons too, he noted, the 'mood... is 
one of fear. Anything to keep out of war., ${ }^{18}$ By 12 March, he had doubts of his own about military action, though they were not entirely logical. On the one hand he felt an ultimatum unwise, because Hitler was unlikely to back down and there would be war. Nicolson was confident 'we shall win and enter Berlin. But what is the good of that? It would only mean communism in Germany and France...' (Quite why this followed was not explained.) In any case, Nicolson simultaneously argued that the British people would refuse to fight, so that, 'We must swallow this humiliation as best we may and be prepared to become the laughing-stock of Europe.' He argued this despite his realisation that, coming on top of the Abyssinian fiasco, it would 'mean the final end of the League...' on which he had previously placed such hope. ${ }^{19}$ Nicolson continued in his confused state for some time. At the Foreign Affairs Committee on 17 March, attended by more than two hundred MPs, he 'made an able and forceful speech reminding the meeting of the extent of the Locarno obligation' and urged that Britain should 'restrain France but not betray her.'20 Then again, his position was far from unique. As James Emmerson remarked in his analysis of the Rhineland crisis, 'most persons who later came to be identified with antiappeasement' - Nicolson, Vansittart, Robert Boothby, even Winston Churchill accepted that the use of force was impossible at this point. And in this, of course, they were at one with the government, whose Foreign Secretary was another figure later identified as an anti-appeaser, Anthony Eden. ${ }^{21}$

In his second Commons' speech, on 26 March 1936 Nicolson revealed his admiration for Eden by praising a statement he had made as 'one of the most telling and effective... ever delivered in this House.' Nicolson also betrayed a feeling that Germany's case was not without merit, regretting that Britain had not been more 
willing to resuscitate her in the 1920s. 'When... Stresemann came into power and there was a real chance of being able to build up all that is best in German life and character, we did not give that encouragement which we should have tendered... Now, when Germany is strong, we fall upon our knees, we bow our foreheads in the dust, and we say "Heil, Hitler".' But, of course, his dislike of Nazism was reflected in the last remark and much of his speech was devoted to arguing the need for a policy of deterring German aggression, a policy to be carried out in close co-operation with France:

'Is there any Member in the House who believes that Germany is not a danger? ... I do not advocate a definite practical alliance with France... But I advocate... the closest relationship with France during the critical months that are upon us... We must say, if the frontiers of Holland, Belgium or France are crossed by any country, especially by Germany, we will within such and such a time bring so many forces, ships and aeroplanes in their defence.'

This was clearly much stronger than his approach to the Abyssinian crisis, even if Nicolson added the coda that co-operation with France should only apply 'to the West. It has nothing to do with the East. ${ }^{22}$

Vansittart continued to influence Nicolson's thinking and recognised that, with the Rhineland secure, Hitler would now turn his attention eastwards. They lunched together in late April, when 'Van' argued that 'a German hegemony in Europe means the end of the British Empire' and that 'we have no right to buy Germany off... by offering here a free hand against the Slav countries.' But this came up against Nicolson's doubts about defending eastern Europe - doubts already reflected in his Commons remark that co-operation with France should only apply in the West. He felt Vansittart 'is right in theory but in practice it would be quite impossible for us to 
get the British people to fight Germany for the sake of the Czechs. ${ }^{, 23}$ Nonetheless, a readiness to draw a line somewhere in the sand, over which the dictators should not cross, became a theme in Nicolson's speeches. In late June 1936, with the fall of Abyssinia to Italy, he was sympathetic to the government's predicament and argued that, 'We League people have been shown... by our ineptitude in this Abyssinian question that economic sanctions are not enough. We know, as has already been said, that aggressive violence can only be restrained by force. It is by the organisation, the co-ordination and the planning of force that the new League of Nations must be built. ${ }^{24}$ He did not provide, in any detail, a method to achieve such an aim and, in retrospect, it was clear that the League was a broken reed. But, in the Commons a few days later he came to the defence of the Secretary for War, Alfred Duff Cooper who, while on a visit to Paris, had seemed to advocate an alliance with France. The Opposition argued that this was out of step with official policy but it was clearly to Nicolson's taste. ${ }^{25}$ Meanwhile, his expertise on international questions was recognised when he was asked to become Vice-Chair of the Foreign Affairs Committee, made up of MPs who supported the government coalition. And his views on the need for a strong stand against the dictators, backed by rearmament and an alliance with France, were evident in his writings at the time. In an article in the influential US journal, Foreign Affairs, in July he showed that he now recognised the need to protect eastern European states: he rejected the idea 'that we surrendered Eastern Europe to German hegemony and thereby secured peace, perhaps only for a single generation, with the certainty of an eventually disastrous war. ${ }^{26}$

Much of Nicolson's attention in late 1936 was absorbed by the abdication crisis and by November 1936, when he was asked to second the Address to the Throne, the international scene was more settled. On this occasion, when he was in 
any case expected to avoid controversy, Nicolson's views, apart from some jibes at Mussolini, seemed well in line with government policy. ${ }^{27}$ During 1937 he made only a few speeches in the Commons. His most significant remarks were about the Spanish civil war, where he was pro-Republican ('If I were to say in the House what I think about Franco I should use the most turbulent language ${ }^{28}$ ) yet opposed British intervention (partly because he feared that this would justify Italian and German intervention on a larger scale $\left.{ }^{29}\right)$. The war appalled him. After the bombing of Guernica by the German air force in April he wrote of his feeling 'that barbarism is creeping over the Earth again and that mankind is going backwards. ${ }^{30}$ Aside from Spain, the dictators created no crises but Nicolson's diary shows that he was concerned about their rising strength. In November he had a long talk with Winston Churchill about the balance of air power in Europe, which led to the conclusion that 'we are... not in a position to go to war without very active Russian assistance.'31 Nicolson recognised - as the government, since May 1937 under Neville Chamberlain did - that 'we cannot fight Germany, Italy and Japan at the same moment.' But he was also impressed by the argument of Conservative MP Duncan Sandys that 'if Germany wishes to attack us, she will do so in any case, and her present policy is to get as much as she can meanwhile without war. ${ }^{32}$ Yet, the situation no longer seemed pressing. Addressing the Foreign Affairs Committee in December, Eden said there was 'no imminent likelihood of war and a far better prospect of appeasement than ever before. ${ }^{33}$ Major differences over appeasement - not a term that Nicolson himself used much - would become obvious only the following year. 


\section{Chamberlain and Eden}

The sense of calm did not last. The event that really seems to have turned Nicolson against the National government's foreign policy was not some action by the dictators but the resignation of Anthony Eden in February 1938, after differences with Chamberlain over how best to deal with Mussolini. As seen above, Nicolson had no liking for Italy's diplomatic style or its dictator; but the MP was an admirer of Eden and regularly praised him in the Commons. In July 1937 he told the Commons, 'I feel that our present Secretary of State for Foreign Affairs does represent in his person the greatest possible agreement that this country in foreign affairs could hope to achieve. ${ }^{34}$ Early in 1938, differences between Chamberlain and Eden came to a head when the Prime Minister was keen to enter into conversations with Mussolini and offer concessions - notably the recognition of Italian rule in Abyssinia - while Eden, who suspected that Mussolini was about to back a German invasion of Austria, argued that there should be no precipitate concessions. The Foreign Affairs Committee of 17 February, well aware of the differences within the Cabinet, was sympathetic to Eden. According to Leo Amery, Nicolson spoke 'vigorously and... pessimistically.' His line was that Hitler was fully in control in Germany and bent on adventurism, while Mussolini had sided with the German leader. Britain should 'keep a stiff upper lip... wait, and above all, arm.' Nicolson himself was delighted to find that the Committee, which was also addressed by Churchill, 'no longer believe that we can buy Germany off with concessions. ${ }^{35}$ The potential for a political crisis only worsened on the $20^{\text {th }}$, when Eden resigned.

But the crisis was over almost as soon as it began. Before the Commons on 21 February, Eden, in Nicolson's own words, 'did not really make a good speech'. He 
made it seem as though, by insisting that the time was not quite right for talks with Italy, he had resigned on a point of detail. In the ensuing debate, an angry Nicolson proved more Edenite than Eden, insisting that in fact 'a great question of principle' was a stake. He returned to his old theme that Italian diplomats had to be handled carefully. 'It is the problem whether a country which has continuously, consistently, deliberately and without apology, violated every engagement into which she has ever entered can be taken back into the fold with a smile; or whether it is better to make a few concrete conditions before negotiations are resumed.' He talked of what he called the 'corkscrew' approach of the Italians: 'They have a perfect system of inventing something that they do not want, of clamouring for the thing they do not want, of saying they will die if they do not get it, and then when they get it, of asking for something else.' Thus, 'it would be foolish... to re-enter negotiations with Italy without first obtaining certain concrete guarantees.'

This time Nicolson did not pull his punches in attacking government policy. Instead he launched into a vitriolic attack on the Prime Minister, which had preechoes of what would be said after Munich: 'the Prime Minister comes here this evening and, with a gesture of triumph, produces Count Grandi's little note... The Prime Minister said that that document was a splendid bit of give-and-take. So it is. We give and they take.' All the Italian foreign minister had offered, argued Nicolson, was to withdraw some troops from Spain, 'where they ought never to have been in the first place.' Ultimately, he claimed, the Italians would ask for a share in controlling the Suez Canal. He risked losing his audience with reflections on Italian policy that went all the way back to 1882 but he ended on a high moral note: 
The late Foreign Secretary struggled hard to preserve the rule of law and order, the theory of the League of Nations, the belief in the sanctity of treaties, and the confidence of the world — which we may lose by this action. However weak we might be, however divided, however muddle-headed; although we might sometimes be frightened, and sometimes misled, we never definitely defended wrong with cool and planned deliberation as we are doing now.

Those who came up to congratulate him afterwards included Churchill and Lloyd George. $^{36}$

Support for Eden could have proved costly for Nicolson, especially since he abstained on Labour's 22 February censure vote. Both the Conservative majority and his own National Labour colleagues condemned him; and there was opposition from within his Leicester constituency. 'Chips' Channon, a loyal Chamberlainite MP, considered that in his speech of 21 February Nicolson 'did the cause of peace as much harm as he could. ${ }^{37}$ At the Foreign Affairs Committee on 25 February, the atmosphere was 'most unpleasant'. Nicolson had heard that there would be an attempt to force the resignation of himself and the chair, Conservative MP, Paul EmrysEvans, who had also abstained. The pair decided that, in the circumstances, they would be better off resigning on their own initiative, but - ironically - the proChamberlain majority realised that this could embarrass the government and so urged them to wait. ${ }^{38}$ After these stressful events, Nicolson decided to 'lie low for the moment.' Such moderation upset a fellow anti-appeaser, Violet Bonham Carter, but Nicolson now argued, curiously, that 'Chamberlain must be given a chance. ${ }^{, 39}$ Nor, was he so much opposed to the Prime Minister as to want to join 'the Winston 
brigade', still preferring to hope for a lead from the more respectable Eden. Or so he told his wife. ${ }^{40}$ But Nicolson remained deeply concerned about the international situation and he did sometimes meet with Churchill and the latter's supporters, such as Boothby. ${ }^{41}$ On 9 March he was involved in a depressing meeting at the Royal Institute of International Affairs, where the feeling was that Britain and France together could not stand up to the German-Italian combination. Later he dined with another anti-appeasement MP, Edward Spears, and Vansittart, who now believed it impossible to prevent Germany dominating Eastern Europe. 'We are suddenly faced by the complete collapse of our authority, our Empire and our independence. ${ }^{42}$

Any hope that central Europe could escape Nazi domination was dented in mid-March when Hitler invaded Austria unopposed. On the 16th, Nicolson spoke during another debate about Spain, when he drew together a number of points in his thinking. He spoke of his 'very deep hatred' for Franco and accused Chamberlain of underestimating the dangers of the situation. Britain might soon see 'the establishment at vital strategic points of Italian and German batteries and submarine bases' in Spain, threatening the Royal Navy's control of the Mediterranean. Nicolson pressed the need to look at the situation, not in emotional terms, but from a strategic perspective and he again urged close co-operation with France. On the surface his arguments seemed hard-headed enough. ${ }^{43}$ But, after he had finished, a note was passed along the benches from the Prime Minister. What, precisely, did Nicolson expect the government to do? 'Occupy Minorca', was the response. At this, Chamberlain flung 'back his head with a gesture of angered despair. ${ }^{44}$ The reaction is hardly surprising. Violent action by the British government at this point, would have justified similar action by the 
dictators, caused confusion at home and lost the morale high ground abroad. Nor is it clear what strategic gain would be made from seizing Minorca, when the Royal Navy already had a chain of Mediterranean bases. Nicolson's suggestion smacked of desperation when put on the spot by the Prime Minister. Yet it was the only precise proposal he could think of.

Chamberlain and his supporters now numbered Nicolson among 'the insurgents'. ${ }^{45}$ But Malcolm Macdonald, the National Labour leader, worked to moderate Nicolson's opposition to the government ${ }^{46}$ and, for a time, he became quiescent. In April, after weeks of pressure for him to do so, Nicolson resigned his position as co-chair of the Commons' Foreign Affairs Committee. Emrys-Evans resigned alongside him. ${ }^{47}$ After that he avoided saying anything in Commons debates so that, by the Summer, "the general impression [is] that I have "dropped out". ,48 Meanwhile, Eden too showed no sign of taking a lead against Chamberlain. In conversation with Nicolson in May, the former Foreign Secretary seemed worried above all by the danger of splitting the country into hostile camps on foreign policy. 'He is himself determined to do everything to prevent such a split. ${ }^{49}$ Nicolson was encouraged by the so-called 'May Crisis' over Czechoslovakia, when Hitler seemed to back off from an invasion of the country (though actually he had no intention of acting at that point). Nicolson believed this showed 'strength and justice' could work and that war might be avoided if Britain rearmed. 'Hitler has for the first time been checked', Nicolson wrote, which might mean that Britain could 'negotiate with the Germans on equal terms.' It is significant that negotiation, not conflict, remained his hope. ${ }^{50}$ 
Nicolson's anti-appeasement activities went on away from the Commons chamber at this time. In the first half of 1938 he attended meetings of the so-called 'Salter's Soviet' at All Souls, Oxford. Arthur Salter, Professor of Political Theory, was a former civil servant who successfully stood as an anti-Chamberlain candidate in a 1937 by-election. A desire to resist the tide of dictatorship was central to the group but they fell out over how best to achieve this, with Nicolson taking a sceptical view of the possibility of negotiation with Hitler while others were reluctant to rule out talks. ${ }^{51}$ There were similar disagreements within the National Labour leadership. ${ }^{52}$ His anti-appeasement views were also reflected in his publications, as in a critique of the idea that German co-operation might be secured through colonial concessions. ${ }^{53}$ In June 1938 Nicolson set out his private thoughts on the international situation in his diary. Chamberlain, he feared, was ready 'to give Germany all she wants at the moment, and cannot see that if we make this surrender we shall be unable to resist other demands.' He also feared that Germany and Italy aimed to divide Britain from France. However, if Britain stood up to Germany it could provoke a war that London would lose, so that perhaps a policy of buying time was the best course. An alliance with Russia was impossible because the British 'governing classes' had an intense 'hatred of the Reds.' Unsurprisingly, after such a circuitous argument, Nicolson retired to bed 'in gloom. ${ }^{54}$ His problem by now was clear: he recognised that the dictators could not be bought off with concessions; that, in other words, appeasement would fail. Yet he could not produce any coherent alternative to Chamberlain's policy.

\section{Munich}


In late August and early September 1938, Nicolson's thoughts were dominated by the looming Czechoslovakian crisis, as it became evident that Hitler might launch a military strike across the border. His earlier doubts about resisting Hitler in the East had now disappeared. He saw the new crisis as 'the final struggle between the principle of law and the principle of violence, and was increasingly concerned that Chamberlain would back down. ${ }^{55}$ But when, on 14 September, it was announced that Chamberlain would make a personal visit to Hitler at Berchtesgarden, Nicolson wrote that the "first feeling is one of enormous relief. ${ }^{56}$ With his wife arguing that the Sudeten Germans had a right to self-determination and the indecisive Eden insisting that he did not 'wish to lead a revolt or to secure any resignations from the Cabinet', it is not surprising that Nicolson felt heavy-hearted. ${ }^{57}$ The Prime Minister flew off to Germany again on 22 September, as Churchill mounted an intense campaign against what he called 'the complete surrender of the Western democracies to the Nazi threat of force. ${ }^{58}$ At this point Nicolson was involved in a number of fraught meetings with other anti-appeasers. On the $22^{\text {nd }}$ he was at Churchill's flat to discuss possible tactics against Chamberlain. Four days later, when it seemed there might yet be war - thanks to Hitler's increased demands in his second summit with Chamberlain - Nicolson was at the flat again along with Leo Amery, Boothby, Harold Macmillan and others, where it was agreed that, 'If Chamberlain rats again we shall form a united block against him.' Believing war to be imminent, the group wanted a coalition government, a blockade of Germany, national service and an approach to Russia. ${ }^{59}$ But in the Commons on 28 September, Chamberlain announced his third and final visit to Germany for the Munich conference. Nicolson was one of the few MPs to refuse to rise as a tribute, drawing the remark from someone behind him, 'Stand up, you brute!' Once again, he felt a sense of relief in Chamberlain's summit diplomacy, 'But my 
moral anxieties are in no way diminished. ${ }^{60}$ At Munich the concession of the Sudetenland to Germany was finally settled. While the conference was underway, Nicolson attended the meetings at which Churchill tried to mobilise key MPs to sign a letter to the Prime Minister, warning him against any more concessions to Hitler. Eden and the Labour leader, Clement Attlee, refused to sign however, leaving Churchill - and Nicolson - despondent. ${ }^{61}$ Meanwhile, the BBC and the Foreign Office pressed Nicolson to avoid 'alarmist' warnings about war, and even criticisms of Nazism, in his broadcasts for The Past Week. ${ }^{62}$

While others lauded the Prime Minister for avoiding war at Munich, Nicolson nailed his colours to the anti-Chamberlain mast. At first he did so inadvertently, during a speech in Manchester on 1 October that caused a minor storm, because it supposedly - contained a personal attack on the Prime Minister's key adviser, Horace Wilson. In fact the speech was misrepresented, because the newspapers based their reports on a draft version released by the National Labour party. ${ }^{63}$ At the same time, Nicolson became more closely identified with 'Winston's dissentients', meeting with them to discuss tactics in the Commons. ${ }^{64}$ His most famous contribution to the case against appeasement was his speech during the Munich debate of 5 October 1938. Here he rejected the idea that the crisis could somehow be blamed on Czechoslovakia itself or that the country was an 'artificial' creation of the Paris peace conference. He also rejected the argument that the question was solely a procedural one, to do with the fate of the Sudetenland (indeed, he conceded the case for separating the region): rather, 'it is essentially the problem whether... Germany is the dominant country in Europe.' His logic was that Germany had now achieved such dominance. 'That is the essential thing, the thing which we ought to have resisted, the thing which we still ought to resist...' It was this point that led him to speak of 'this defeat, this 
humiliating defeat, this terrible Munich retreat.' Bulgaria, Rumania and Yugoslavia would, he argued, now strike deals with Hitler. He guessed that the whole of eastern Europe would be at Hitler's feet in three months. Nicolson wrote off the 'piece of paper' Chamberlain had brought back as making 'friends with the strong against the weak.' For Nicolson it represented nothing less than the end of hundreds of years of balance of power diplomacy, designed 'to prevent by every means in our power the domination of Europe by any single Power or group of Powers.' He was not without some sympathy for 'all the excellent intentions, all the admirable courage and all the lonely dignity which the Prime Minister displayed', but he felt that Chamberlain had shown 'a lack of understanding of foreign mentality' and he ended the speech on an emotional note: 'I know that those of us who believe in the traditions of our policy... are accused of possessing the Foreign Office mind. I thank God that I possess the Foreign Office mind. ${ }^{65}$

When it came to the vote Nicolson joined Churchill, Eden, Duff Cooper (who had just resigned from the government), Amery, Macmillan and over twenty other Conservative MPs in abstaining. 'The House', he believed, 'knows that most of the above people know far more about the real issue than they do.' This was not mere vanity. In similar vein Oliver Harvey, Private Secretary to the Foreign Secretary, considered 'all the good speeches were against the government' and listed Nicolson's among them. ${ }^{66}$ His behaviour caused renewed ructions within his Leicester constituency but Nicolson continued to identify with other anti-Chamberlainites. ${ }^{67}$ In November, with a dozen Conservative MPs, including Amery, Duff Cooper and Macmillan, he attended a 'hush-hush meeting' with Eden where they finally agreed to form their own group - though they would not advertise it as such - meeting occasionally to discuss the international situation and 'organise ourselves for a revolt 
if needed.' Yet, even now, all was not as it seemed. Nicolson told his wife he was happy to be 'distinct from the Churchill group' and led by 'wise people' who 'do not mean to do anything rash or violent. ${ }^{68}$ But, once again, such moderation exposed a real weakness in his outlook. The 'Eden Group' lacked robust leadership from the former Foreign Secretary, who continued to hope for a return to office. By the end of the month, Nicolson was complaining that, 'We still do not really constitute a group and Anthony still hesitates to come out against the government. ${ }^{69}$ Nicolson continued to state his own beliefs at public meetings. ${ }^{70}$ But 1939 would see him retreat once more from an active role in the Commons, as he had retreated in the wake of his anger over Eden's resignation.

\section{The Coming of War}

In early February 1939, Nicolson was predictably delighted with Chamberlain's announcement to the Commons of a closer relationship with France, amounting as this did to a military alliance. It seemed the Prime Minister had 'swung suddenly round to all that we have been asking for,' he told his wife, 'I think it can only mean that he realizes that Appeasement has failed.' Chamberlain might even become an asset, because, 'No ordinary German or Italian will ever believe propaganda telling him that Chamberlain is a war-monger. ${ }^{71}$ In March, Nicolson even met his constituency chair's wish for a statement 'saying that I agree with the government's present policy. Which I do.' A letter to his wife, however, revealed that he had few illusions about why the 'ladies of Leicester' needed such a statement. They were worried by the world situation and eager to trust in Chamberlain, who 'has rendered cowardice and treachery respectable. ${ }^{72}$ With the collapse of the Munich agreement 
shortly afterwards, Nicolson could have driven home the point that the anti-appeasers had been proven right and the Prime Minister wrong. But, as Hitler marched on Prague, Nicolson felt it 'merely renders explicit facts that since Munich were implicit $^{73}$ and his speech in the Adjournment debate of 3 April 1939 seemed a world away from his intervention of six months before. He began by declaring his wish 'to add my pebble to that great bastion of support which the Prime Minister must feel that he has now behind him' and could even find some retrospective praise for the events of the previous September. Nicolson believed that Chamberlain had convinced the Germans of his interest in peace and that they did not welcome the breech in the Munich agreement. He also felt that Hitler's anti-semitic atrocities, with their 'cold and deliberate sadism', had alienated many Germans. He wanted a propaganda campaign to be pressed by the BBC and the British Council to explain the British case to the German people and convince them that peace was possible. ${ }^{74}$ In this, as Drinkwater says, he missed 'the obvious point that, even if the majority of Germans and Italians regarded Chamberlain as a man of peace, they were ruled by men to whom this was irrelevant. ${ }^{75}$

It was not that Nicolson ceased to have doubts about Chamberlain's policy, but he does seem to have been ready to accept that the Polish guarantee, given by Britain in the wake of Hitler's destruction of Czechoslovakia, marked a real change in foreign policy. ${ }^{76}$ Behind the scenes he continued to associate with Churchill, joining the latter in a discussion with the Soviet ambassador, Ivan Maisky, to discuss a possible alliance. ${ }^{77}$ And by mid-April Nicolson feared that Chamberlain, under the influence of Horace Wilson, might already be returning to his old belief in Appeasement. ${ }^{78}$ But in the Commons he said nothing to suggest such deep concern. Robert Boothby complained about his friend's weakness at this time, only to receive 
the reply that 'old queens like myself are capable of hysterical heroism but are not good at the constant fight. ${ }^{79}$ As his fears grew about 'another Munich over Danzig', any desire Nicolson might have to put his head above the parapet was probably deflated by Eden, who continued to miss 'every boat with exquisite elegance' when it came to criticising the Prime Minister. ${ }^{80}$

On 31 July 1939, in his last Commons speech before the outbreak of war, Nicolson seemed bent on securing peace both at home and abroad. His logic was that 'the way of appeasement... is dead' and that 'the way of peace' had now become the 'proper focus.' He began by defending Eden: 'seldom in the history of any political controversy, any political disagreement, has such moderation been shown, such extreme consideration been displayed, such reticence, almost, been exercised, as has been shown by my right honourable Friend in the unhappy controversy that arose after his retirement.' At home Nicolson hoped to abolish 'this ridiculous duality between appeasers and resisters', building an 'agreement that there must be the maximum of resistance first, and thereafter the maximum of conciliation.' Abroad, he feared that such conciliation could prove difficult because 'war has become a vested interest in Germany' and the whole economy had become geared to armaments production. The solution was to make 'it clear to Hitler that victory is a physical impossibility and that peace is a physical possibility.' And as part of this policy Nicolson specifically urged that Britain should offer loans to help Germany through a process of disarmament. He wanted an inspection regime to oversee such disarmament and he wanted the Nazis to withdraw from Czechoslovakia. ${ }^{81}$ It was another odd display, as high on moral principle as it was thin on practicalities. It showed that he still hoped for a negotiated settlement, albeit from a position of strength. Yet, as war approached over the following weeks he reverted to his belief 
that a deal with Hitler was impossible, that Chamberlain's attempts at maintaining the peace were wrong and that war had to be faced. ${ }^{82}$

The outbreak of war saw Nicolson in a gloomy mood. He admitted, 'there is a little timid, selfish side of myself that tempts me by still murmurings to hope that we shall reach a form of appeasement after the Germans have conquered Poland'; but he immediately added that 'the real thing in me loathes and detests any such capitulation. ${ }^{83}$ During the 'phoney war' he continued to criticise Chamberlain's performance - 'no gift for inspiring anybody' and 'one feels the confidence and spirits of the House dropping inch by inch' were just two comments on the Prime Minister's speeches ${ }^{84}$ - and remained part of the Eden Group' (though Eden himself had now rejoined the government). His criticism of Chamberlain's diplomacy was evident once more to the public when he authored a Penguin Special, Why Britain is at War in December 1939. Here he likened the Prime Minister and Horace Wilson on the international stage to 'two curates entering a pub for the first time; they did not observe the difference between a social gathering and a rough house... ${ }^{95}$ Nicolson also continued to exchange views with Vansittart ${ }^{86}$ and recognised Churchill's gifts as a potential leader. By late September 1939, with the prospect of defeat heightened by the Soviet invasion of eastern Poland, he wrote that 'Churchill might be our Clemenceau or our Gambetta' and in October was involved in a discussion in the Eden Group about his replacing Chamberlain. ${ }^{87}$ In the vote of May 1940, when Chamberlain's majority crashed to only 81 , Nicolson was among those who voted against him, helping bring Churchill into office.

\section{Conclusion}


What might be said by way of an overall interpretation of Nicolson's approach to Appeasement? He gained an early reputation as an anti-appeaser and his public line certainly embraced a certain logic. He had a visceral dislike of dictators and saw Italian and German policy as an ideological menace as well as a threat to British security. He hated the Spanish civil war and was appalled by the results of Nazi antisemitism in Austria. 'We stand for tolerance, truth, liberty and good humour. They stand for violence, oppression, untruthfulness and bitterness. ${ }^{88} \mathrm{He}$ also wanted to see the government make a stand at some point. In his speech following the remilitarisation of the Rhineland he insisted that, 'It is no use merely to express virtuous intentions. We must act in such a way that the countries of EuropeGermany above all—must say, "This time they really mean it".' He always deeply believed in co-operation with France, at least in terms of security in western Europe. In his Commons speeches, he said nothing specific about some of the problems that concerned the government, such as the threat from Japan or Britain's economic weakness. But it is clear from his diaries and other sources that he thought about such problems. In 1937 he considered that an agreement between Britain, the US, German and Japan to develop China would provide business for those factories that were diverted from arms production, neatly combining the desire for peace, the problems of East Asia, the need to stimulate the world economy and, it must be said, the potential for 'economic appeasement' ${ }^{89} \mathrm{He}$ was not a firm advocate of a Soviet alliance in 1936-38, but he was friends with the Soviet ambassador, Ivan Maisky, he complained about Chamberlain's anti-Russian outlook ${ }^{90}$ and in 1939 he saw the logic of Churchill's arguments in favour of a Soviet alliance. He was also willing to run risks for his beliefs, alienating other members of National Labour, their Conservative allies and his constituency party with his criticisms of Chamberlain. 
Nonetheless, a chronological look at Nicolson's thoughts and statements on British foreign policy in 1935-39 shows that, whatever his dislike of the dictators, his attitude towards appeasement was volatile. Down to February 1938 he did not differ substantially with government policy. Nicolson's rejection of military action during the Rhineland crisis led David Carlton to refer to him merely as 'a so-called antiappeaser' ${ }^{91}$ Nicolson was not alone in being a critic of Munich, having earlier refused to stand up over the Rhineland. David Dutton has highlighted Eden's desire, as Foreign Secretary, for a modus vivendi with Hitler while simultaneously pursuing rearmament: 'If this was appeasement through strength, it was appeasement nonetheless.' It was a policy supported by another of Nicolson's influences, Robert Vansittart. ${ }^{92}$ Of course, it is possible to defend those who took such views at a time when Hitler did no more than 'march into his own backyard.' Norman Rose has argued that, in 1936, Nicolson was reluctant to march ahead of public opinion, reluctant to distance himself from the government (especially with Eden as Foreign Secretary) and 'at a loss' to know how to deal with Hitler. ${ }^{93}$ And, again, in this he was not alone. Besides, surely his opposition to appeasement in 1938 is what matters? By the time of Munich, Nicolson came to see appeasement as meaning one-sided concessions in a vain attempt to buy off the dictators and he was prepared even to stand up for eastern European countries. As he put it in April 1939, when appeasement seemed to have collapsed: 'I have always contended that Germany wanted only one things and that was power. Now, power is an expanding ambition and it is impossible to fix its frontiers. Chamberlain and the appeasement folk imagined that you could. ${ }^{94}$ Yet, even during 1938 itself he showed signs, during the middle of the year, before the Munich crisis loomed, of withdrawing from the front line, even if he remained very active behind the scnes. Again, during the first seven 
months of 1939 - though he remained active as a speaker, writer and broadcaster Nicolson's few parliamentary speeches suggest a backing away from his earlier attacks on the Prime Minister, a readiness to value him as a Man of Peace and, perhaps more significant, a willingness to use economic concessions to wean Hitler from his wish for war. But for the most part he seemed to withdraw again from parliamentary life, having nothing to say in the Commons during the crisis over Poland, even if his dislike of Chamberlain was clear enough to those around him.

As Derek Drinkwater has argued, Nicolson had a 'liberal realist philosophy of international relations', rejecting utopian solutions to the world's problems but also appreciating the dangers of power politics. His belief in the League of Nations in 1935-37 was based on a desire to avoid dividing Europe into alliance blocs, such as had occurred before 1914. But, within this liberal idealist outlook, his views could range quite widely. ${ }^{95}$ Aside from an inevitable evolution in his thinking over time, this chapter has also shown that he was influenced by events and individuals around him. These included not only the actions of the dictators or the behaviour of his own government, but also the attitudes of his wife and his friends, the carping from his constituency party, the criticism his fellow MPs and the behaviour of the less-thanheroic Eden. Nicolson was determined to work with the Eden group rather than with Churchill and this may be one reason why he never became close to the wartime Prime Minister. In mounting a campaign against appeasement, Nicolson was also affected, in a negative sense, by his own self-doubt and feelings of depression, by his decency and moderation, perhaps by his Englishness, which he once summed up as implying a 'habit of compromise, gradualness and the middle path between extremes. ${ }^{96}$ As one of his biographers has written, Nicolson lacked the 'spirit of leadership... He was too soft and sentimental. ${ }^{97}$ 
Criticisms from without and self-doubt within: these explain his withdrawals from the political fray in mid-1938 and after October 1938. He did not have the nerve or commitment necessary for the long haul, whilst the same sensitivity that made him an anti-fascist made him long for peace. 'What I need', he told his wife in the wake of the Rhineland crisis, "is a feeling that we shall avoid war. ${ }^{98}$ This desire, somehow, to avoid war made him feel powerless, as reflected in another, highly sentimental letter to her a few months before war came: 'We wish only to do good on earth. We are not vulgar in our tastes or cruel in our thoughts. Why is it that we are impotent to prevent something that we know to be evil and terrible? ${ }^{99}$ In analysing world affairs he could be lucid and intelligent, but equally he had an almost naïve belief in the significance of national traits, as in his attack on Italian diplomatic methods after the Hoare-Laval pact. ${ }^{100}$ Above all, while confident of the need to resist aggression, rearm and cooperate with other nations, he never could produce a coherent alternative to appeasement. Neither, it might be said, did Eden or Churchill. But after his suggestion that Britain had best occupy Minorca, it is probably understandable that Chamberlain did not see Harold Nicolson as a source of sound advice on how best to deal with the fascist menace. 


\section{Notes}

\footnotetext{
${ }^{1}$ For biographies see: James Lees-Milne, Harold Nicolson, a biography (2 vols, London: Hamish Hamilton, 1988); and Norman Rose, Harold Nicolson (London; Jonathan Cape, 2005). Also valuable is Denis Drinkwater, Sir Harold Nicolson and International Relations: the practitioner as theorist (Oxford: Oxford University Press, 2005). Excellent as these are, they are all, to my mind, rather too generous to Nicolson when it comes to dealing with his opposition to appeasement.

2 Thomas Otte, 'Nicolson', in G.R. Berridge, Maurice Keens-Soper and Otte, Diplomatic Thoery from Machiavelli to Kissinger (Basingstoke: Macmillan, 2001), 171.

${ }^{3}$ For a review of the literature see Sidney Aster, 'Appeasement: before and after revisionism', Diplomacy and Statecraft, vol. 19, no. 3 (September 2008), 443-80. David Dilks' key contribution was 'Appeasement Revisited', University of Leeds Review, vol. 15 (1972), 51-64.

${ }^{4}$ Andrew David Stedman, Then want could Chamberlain do, other than what Chamberlain did? A synthesis and analysis of the alternatives to Chamberlain's policy of appeasing Germany (PhD, University of Kingston, 2007).

${ }^{5}$ Nigel Nicolson, ed., Harold Nicolson: diaries and letters, 1930-39 (London, Collins, 1966), 97, entry of 24 November 1931.

${ }^{6}$ Nicolson to Sackville-West, 3 January 1932, in Nigel Nicolson, ed., Vita and Harold: the letters of Vita Sackville-West and Harold Nicolson (New York, Putnam’s, 1992), 231. See also Nicolson, ed, Diaries, 1930-39 (hereafter 1930-39), 108, 24 January1932, for further comments, including

'Hitlerism... is a doctrine of despair.'

${ }^{7}$ 1930-39, 106, 6 January 1932.

8 1930-39, 108, 24 January 1932.

${ }^{9}$ Nicolson to Sackville-West, 4 August 1938, in Nicolson, Vita and Harold, 304-6.
}

${ }^{10}$ HC Deb. 5s, vol. 307, cols 2076-81, 19 December 1935. Similarly, in June 1936, he argued that 'the personal mission of a Minister abroad is the most dangerous form of diplomacy which can possibly exist': HC Deb. 5s, vol. 314, col. 131. All quotes from Hansard are via http://hansard.millbanksystems.com/commons [accessed 6 June 2009]

11 1930-39, 233, 19 December.

12 1930-39, 243, 13 February 1936.

${ }^{13}$ Robert Rhodes James, ed., Chips: the diaries of Sir Henry Channon (London: Weidenfeld and Nicolson, 1967), 59, 27 February.

${ }^{14}$ At some points these became quite frequent, as in early 1938: 1930-39, 322 (17 February), 327 (28 February), 330 (9 March) and 334 (11 April).

${ }^{15}$ For a recent discussion see Keith Neilson and Thomas Otte, The Permanent Under-Secretary for Foreign Affairs (London: Routledge, 2009), chapter 7.

${ }^{16}$ Harold Nicolson, Why Britain is at War (Harmondsworth: Penguin, 1939), 56.

${ }^{17}$ Nicolson to Sackville-West, 11 March 1936, in Nicolson, Vita and Harold, 280-81.

18 1930-39, 248, 9 March.

19 1930-39, 249-50, Nicolson to Sackville-West, 12 March.

${ }^{20}$ John Barnes and David Nicholson, eds., The Empire at Bay: the Leo Amery Diaries, 1929-45

(London: Hutchinson, 1988), 411, entry of 17 March 1936; 1930-39, 252, 17 March.

${ }^{21}$ J.T. Emmerson, The Rhineland Crisis (London: Maurice Temple Smith, 1977), 145.

${ }^{22}$ HC Deb 5s, vol. 310, cols. 1468-72, 26 March; 1930-39, 254, 26 March 1936. Nicolson pursued similar points about the Rhineland in talking at Chatham House: Rose, Nicolson, 196-7.

${ }^{23}$ 1930-39, 259, reproducing Nicolson to Sackville-West, 28 April.

${ }^{24}$ HC Deb. 5s, vol. 313, cols. 1663-68, 23 June.

${ }^{25}$ HC Deb. 5s, vol. 314, cols. 131-5, 29 June.

${ }^{26}$ Harold Nicolson, 'Has Britain a Policy?', Foreign Affairs, vol. 14, no. 4 (July 1936), 561.

${ }^{27}$ HC Deb. 5s., vol. 317, cols. 17-21, 3 November.

${ }^{28}$ HC Deb. 5s, vol. 326, col. 1892, 19 July 1937. 
${ }^{29}$ HC Deb. 5s, vol. 322, col. 1095, 14 April.

${ }^{30}$ Nicolson to Sackville-West, 29 April, in Nicolson, Vita and Harold, 294-5.

${ }^{31}$ 1930-39, 312-13, 15 November.

32 1930-39, 313, 18 November.

${ }^{33}$ 1930-39, 314-15, 9 December.

${ }^{34}$ HC Deb. 5s, vol. 326, col. 1893, 19 July.

${ }^{35}$ 1930-39, 323, 17 February 1938; Barnes and Nicholson, Amery Diaries, 455, entry of 17 February;

Earl of Avon, The Eden Memoirs: Facing the Dictators (London: Cassell, 1962), 579-80.

${ }^{36}$ 1930-39, 323-5, 22 February; HC Deb. 5s, vol. 332, cols. 99-104, 21 February.

${ }^{37}$ James, ed., Chips, 145, 21 February.

${ }^{38}$ Nicolson to Sackville-West, 25 February 1938, in 1930-39, 325-7; Barnes and Nicholson, Amery Diaries, 458, entry of 24 February; and on Emrys-Evans as an anti-appeaser see Lynne Olson, Troublesome Young Men: the rebels who brought Churchill to power (New York: Farrar, Straus and Giroux, 2007), 101-03.

39 1930-39, 327, 28 February.

${ }^{40}$ Nicolson to Sackville-West, 2 March, in Nicolson, Diaries, 1930-39, 327-8.

${ }^{41}$ 1930-39, 332, 16 March.

${ }^{42}$ Nicolson to Sackville-West, 9 March, in Nicolson, Vita and Harold, 297-8.

${ }^{43}$ HC Deb. 5s, vol. 333, cols. 521-24, 16 March. And see 1930-39, 332, 29 March 1938.

${ }^{44}$ 1930-39, 331-2, 16 March 1938.

${ }^{45}$ James, ed., Chips, 153, 22 March.

46 1930-39, 333, 29 March.

47 1930-39, 333, 7 April.

48 1930-39, 348, 30 June.

49 1930-39, 339, 11 May.

${ }^{50}$ Nicolson to Sackville-West, 30 May, reproduced in Nicolson, Vita and Harold, 301; 1930-39, 344, 23 May.

${ }^{51}$ See A.L. Rowse, All Souls and Appeasement (London: Macmillan, 1961), 59-60; Sidney Aster,

“'Salter's Soviet": another view of All Souls and appeasement,' in M.G. Fry (ed.), Power,

Personalities and Policies: essays in honour of Donald Cameron Watt (London: Frank Cass, 1992), 144-74; Rose, Nicolson, 209-11.

${ }^{52}$ N.A. Rose, ed., Baffy: the diaries of Blanche Dugdale, 1936-47 (London: Vallentine Mitchell, 1973), 65, entry of 2 November 1937.

${ }^{53}$ Harold Nicolson, 'The Colonial Problem', International Affairs, vol. 17, no. 1 (January 1938), 32-51.

${ }^{54}$ 1930-39, 345-6, 6 June.

${ }_{55}^{55}$ See, for example, 1930-39, 359, 11 September.

${ }^{56}$ 1930-39, 359-60, 14 September.

${ }^{57} 1930-39,360-61,15$ and 19 September.

${ }^{58}$ Churchill press statement, 21 September, reproduced in Martin Gilbert, Winston S. Churchill, vol. V, 1922-39 (London: Heinemann, 1976), 978-9.

${ }^{59}$ 1930-39, 363-8, 22 and 26 September; Barnes and Nicholson, Amery Diaries, 517, entry of 26

September.

60 1930-39, 368-71, 28 September.

${ }^{61}$ 1930-39, 371-2, 29 September.

${ }^{62}$ Lees Milne, Nicolson, volume 2, 109-10.

${ }^{63}$ 1930-39, 359-60, 1 October.

${ }^{64}$ 1930-39, 375, 5 October; Barnes and Nicholson, Amery Diaries, 526, entry of 5 October.

${ }^{65}$ HC Deb 5s, vol. 339, cols. 426-34, 5 October. 
${ }^{66}$ 1930-39, 375-6, 6 October; John Harvey, ed., The Diplomatic Diaries of Oliver Harvey, 1937-40 (London: Collins, 1970), 210.

${ }^{67}$ Nicolson to Sackville-West, 10 October, in Nicolson, Vita and Harold, 307-8.

${ }^{68}$ Nicolson to Sackville-West, 9 November, in 1930-39, 377-8.

${ }^{69}$ 1930-39, 380-81, 24 November.

${ }^{70}$ See, for example, his remarks to the Junior Constitutional Club: 1930-39, 359-60, 30 November.

${ }^{71}$ Nicolson to Sackville-West, 7 February 1939, in Nicolson, Vita and Harold, 308-9.

72 Nicolson to Sackville-West, 297 March, in Nicolson, Vita and Harold, 310-11.

${ }^{73}$ 1930-39, 392, 14 March.

${ }^{74}$ HC Deb 5s, vol. 345, cols. 2524-29, 3 April.

${ }^{75}$ Drinkwater, Nicolson, 155.

76 1930-39, 393, 17 March, with 393-4, 31 March.

77 1930-39, 394, 3 April.

78 1930-39, 397-8, 11 and 19 April.

${ }^{79}$ 1930-39, 402-3,Nicolson to Boothby, 6 June, and for the reply, 9 June, Olson, Troublesome Young Men, 195-6.

${ }^{80}$ 1930-39, 405-6, 18 July.

${ }^{81}$ HC Deb 5s, vol. 350, cols. 2080-84, 31 July.

${ }^{82}$ See especially 1930-39, 411- 22, 23 August-3 September.

${ }^{83}$ Nigel Nicolson, ed., Harold Nicolson: diaries and letters, 1939-45 (London, Collins, 1967), 31-2, 11 September; and see 30, 5 September, for similarly pessimistic thoughts.

${ }^{84}$ Nicolson, Diaries, 1939-45, 35, 20 September, and 37, 26 September.

${ }^{85}$ Nicolson, Why Britain is at War, 106, but see 130-31 for a more sympathetic line on Chamberlain's predicament and the danger of harsh retrospective judgments.

${ }^{86}$ For example, Nicolson, ed., Diaries, 1939-45, 33, 60 and 96.

${ }^{87}$ Nicolson, Diaries, 1939-45, 34-5, 17 September, and 38, 3 October.

${ }^{88}$ 1930-39, 273, 20 September 1936.

89 1930-39, 302, 16 June 1937.

${ }^{90}$ For example, 1930-39, 329, 7 March 1938.

${ }^{91}$ David Carlton, Anthony Eden (London: Allen Lane, 1981), 81.

${ }^{92}$ David Dutton, Anthony Eden: a life and reputation (London: Edward Arnold, 1997), 60.

${ }^{93}$ Rose, Nicolson, 198-9.

${ }_{94}^{1}$ 1930-39, 401, 29 April 1939.

${ }^{95}$ Drinkwater, Nicolson, 15 and see chapter 6 on the inter-war period.

${ }^{96}$ Harold Nicolson, 'British public opinion and foreign policy', Public Opinion Quarterly, vol. 1, no. 1 (January 1937), 53-63.

${ }^{97}$ Lees-Milne, Nicolson, volume 2, 85.

98 1930-39, 259, reproducing Nicolson to Sackville-West, 28 April 1936.

99 1930-39, 404, Nicolson to Sackville-West, 19 June 1939.

100 The same outlook is evident in, for example, his 'What France means to England', Foreign Affairs, vol. 17, no.2 (January 1939), especially 351-3. 